\title{
Expression of trophic amidated peptides and their receptors in benign and malignant pheochromocytomas: high expression of adrenomedullin $R D C 1$ receptor and implication in tumoral cell survival
}

\author{
Erwan Thouënnon*, Alice Pierre*, Yannick Tanguy, Johann Guillemot, \\ Destiny-Love Manecka, Marlène Guérin, L'houcine Ouafik', Mihaela Muresan², \\ Marc Klein ${ }^{3}$, Jérôme Bertherat ${ }^{4}$, Hervé Lefebvre, Pierre-François Plouin ${ }^{5}$, \\ Laurent Yon and Youssef Anouar
}

\author{
INSERM, U982, Laboratory of Neuronal and Neuroendocrine Differentiation and Communication (DC2N), IFRMP23, University of \\ Rouen, 76821 Mont-Saint-Aignan, France \\ ${ }^{1}$ INSERM, U911, Centre de Recherche en Oncologie et Oncopharmacologie, Université de la Mediterranée, Aix-Marseille II, 13385 \\ Marseille, France \\ ${ }^{2}$ Endocrinology Unit, Hôpital ND de Bon Secours, 57038 Metz, France \\ ${ }^{3}$ Department of Endocrinology, Hôpital de Brabois, 54500 Nancy, France \\ ${ }^{4}$ Department of Endocrinology, INSERM, U1016, Institut Cochin, 75014 Paris, France \\ ${ }^{5}$ Hypertension Unit, Hôpital Européen Georges Pompidou, AP-HP, University of Paris-5, 75908 Paris Cedex 15, France \\ (Correspondence should be addressed to Y Anouar; Email: youssef.anouar@univ-rouen.fr) \\ *(E Thouënnon and A Pierre contributed equally to this work)
}

\begin{abstract}
Pheochromocytomas are catecholamine-producing tumors which are generally benign, but which can also present as or develop into malignancy. Molecular pathways of malignant transformation remain poorly understood. Pheochromocytomas express various trophic peptides which may influence tumoral cell behavior. Here, we investigated the expression of trophic amidated peptides, including pituitary adenylate cyclase-activating polypeptide (PACAP), neuropeptide $Y$ (NPY), and adrenomedullin (AM), and their receptors in benign and malignant pheochromocytomas in order to assess their potential role in chromaffin cell tumorigenesis and malignant transformation. PACAP, NPY, and $A M$ are expressed in the majority of pheochromocytomas studied; NPY exhibiting the highest mRNA levels relative to reference genes. Although median gene expression or peptide levels were systematically lower in malignant compared to benign tumors, no statistically significant difference was found. Among all the receptors of these peptides that were analyzed, only the AM receptor $R D C 1$ displayed a differential expression between benign and malignant pheochromocytomas. This receptor exhibited a fourfold higher expression in malignant than in benign tumors. AM and stromal cell-derived factor 1 , which has also been described as a ligand for RDC1, increased the number of human pheochromocytoma cells in primary culture and exerted anti-apoptotic activity on rat pheochromocytoma PC12 cells. In addition, RDC1 gene silencing decreased the number of viable PC12 cells. This study shows the expression of several trophic peptides and their receptors in benign and malignant pheochromocytomas, and suggests that $\mathrm{AM}$ and its RDC1 receptor could be involved in chromaffin cell tumorigenesis through pro-survival effects. Therefore, AM and RDC1 may represent valuable targets for the treatment of malignant pheochromocytomas.
\end{abstract}

Endocrine-Related Cancer (2010) 17 637-651 


\section{Introduction}

Pheochromocytomas are catecholamine-secreting tumors that arise from chromaffin cells of adrenal medulla or extra-adrenal locations, leading to paroxystic or persistent hypertension in most patients. Most of pheochromocytomas occur sporadically, but $\sim 25 \%$ occur as a result of germline mutations in seven genes identified to date. Mutations of the von Hippel-Lindau or VHL tumor suppressor gene predispose to the development of VHL syndrome, those of the neurofibromatosis type 1 (NF1) gene to von Recklinghausen's syndrome, and those of the rearranged during transfection (RET) protooncogene to multiple endocrine neoplasia type 2A and 2B (MEN 2A and 2B). More recently, mutations identified in genes encoding succinate dehydrogenase subunits B $(S D H B), \mathrm{C}$ $(S D H C), \mathrm{D}(S D H D)$, and 5 (SDH5) have been shown to predispose respectively to familial paraganglioma syndromes 4, 3, 1, and 2 (Lenders et al. 2005, Gimenez-Roqueplo et al. 2008, Hao et al. 2009).

Pheochromocytoma generally occurs as a benign tumor, but $10-25 \%$ of cases are malignant at the first surgery or at recurrence, with metastasis development at lymph node, bone, liver, or lung (Manger 2006). Unlike benign tumors which can be diagnosed and surgically treated, there is currently no means to identify, predict, or cure malignant pheochromocytomas. Despite distinction attempts based on biochemical measurements of dihydroxyphenylalanine (DOPA) and dopamine production, histological criteria such as tumor cell necrosis, vascular invasion, number of mitotic figures, $S D H B$ mutation conferring high risk of malignancy, or combined use of these features, it is commonly accepted that malignancy of pheochromocytoma can only be asserted after metastasis appearance (Eisenhofer et al. 2004, Chrisoulidou et al. 2007, Timmers et al. 2009). Furthermore, the pathogenesis of pheochromocytoma, in particular malignancy development, and the underlying molecular pathways are not fully understood.

The neuroendocrine adrenomedullary chromaffin cells synthesize and release numerous peptides that exert trophic activities and regulate secretion in an autocrine/paracrine manner. Such peptides and their receptors may represent valuable tools to develop effective therapies for chromaffin cell neoplasia (Ziegler et al. 2009). In particular, pituitary adenylate cyclase-activating polypeptide (PACAP), neuropeptide Y (NPY), and adrenomedullin (AM) are trophic and secretion-stimulating peptides that have been characterized in normal adrenomedullary as well as pheochromocytoma cells (Ichiki et al. 1994,
deS Senanayake et al. 1995, Turquier et al. 2001, Isobe et al. 2003, Conconi et al. 2006, Zeng et al. 2006). The neuropeptide PACAP is endowed with a neurotrophic activity, exerting neuroprotective effects against various stressors and during cell differentiation (Grumolato et al. 2003a). Moreover, a role for PACAP in angiogenesis has been suggested since it stimulates vascular endothelial growth factor expression in numerous tumoral cell types (Ribatti et al. 2007). PACAP exerts its various effects through activation of PAC1, VPAC1, and VPAC2 receptors (Vaudry et al. 2009). In adrenal medulla, PACAP regulates catecholamine and peptide biosynthesis and release via PAC1-R-activated signaling cascades (Guillemot et al. 2006, Ghzili et al. 2008). In human pheochromocytomas, PACAP and its receptors have been described, suggesting that this neuropeptide may affect tumoral chromaffin cell differentiation and activity (Isobe et al. 2003).

The neuropeptide NPY is now considered as a growth factor for neurons and vascular smooth muscle cells, and has also been described as an angiogenic factor that can induce proliferation and migration of endothelial cells, capillary vessel formation, and revascularization (Hansel et al. 2001, Lee et al. 2003, Pons et al. 2003). In human chromaffin cells, NPY has been shown to positively regulate catecholamine secretion (Rosmaninho-Salgado et al. 2009). Among the six genes, $Y 1, Y 2, Y 3, Y 4, Y 5$, and $Y 6$ that have been described as coding for NPY receptors, $Y 6$ is a pseudogene in human that codes for a truncated nonfunctional protein. Although the existence of $\mathrm{Y} 3$ is highly disputed, this receptor has been reclassified recently as chemokine receptor 4 (CXCR4), a wellcharacterized receptor (Bleul et al. 1996). The receptors $\mathrm{Y} 1, \mathrm{Y} 2, \mathrm{Y} 4$, and $\mathrm{Y} 5$ were characterized in the human adrenal medulla, but no data are available regarding CXCR4 expression in this tissue (Cavadas et al. 2001). In pheochromocytomas, Y1 and/or Y2 receptors were found in 35\% of the tumors analyzed (Korner et al. 2004).

The peptide AM has been initially isolated from a pheochromocytoma and was subsequently found at high concentrations in the adrenal medulla (Kitamura et al. 1993). This peptide is released in circulation where it can exert hypotensive effects, acting on vasodilatation and increasing diuresis and $\mathrm{Na}^{+}$ secretion in urine (Nishikimi 2007). It has also been shown that AM possesses a local proliferative and antiapoptotic action on several cell types, and is implicated in tumoral neoangiogenesis (Ishikawa et al. 2003, Uzan et al. 2008). The peptide AM acts through ADMR, RDC1, and calcitonin receptor-like (CRLR) 
receptors. Although initially described as a receptor for AM, RDC1 has also a high affinity for the chemokine stromal cell-derived factor 1 (SDF1; Kapas \& Clark 1995, Balabanian et al. 2005). The CRLR is associated with the receptor activity-modifying protein 2 (RAMP2) or RAMP3 proteins to form a receptor with higher affinity for AM, or with RAMP1 to form a receptor with higher affinity for CGRP (McLatchie et al. 1998). In chromaffin cells, AM evokes catecholamine release (Mazzocchi et al. 1999), and in pheochromocytomas, the expression of $A M$ and $C R L R$ has been shown, suggesting the possibility of an autocrine/paracrine role of AM in normal and tumoral adrenomedullary cells (Zeng et al. 2006).

In a previous study, we have shown the differential expression in benign versus malignant pheochromocytomas of peptidylglycine $\alpha$-amidating monooxygenase (PAM), the enzyme responsible for the amidation and therefore the stability as well as the activity of PACAP, NPY, and AM (Thouennon et al. 2007), suggesting a potential alteration of the function of these amidated peptides. Because these peptides exert proliferative and/or anti-apoptotic effects on various cell types, positively regulate catecholamine secretion from chromaffin cells in physiological or pathophysiological conditions, and can be linked to angiogenesis which represents an important feature of tumorigenesis, especially in tumors exhibiting high vascularization such as pheochromocytomas, we carried out in the present study a systematic quantitative survey of the expression of these trophic peptides and their receptors in benign and malignant pheochromocytomas. We also examined the effect of AM on rat and human pheochromocytoma cell survival, and the potential implication of the receptor RDC1 which is highly expressed in malignant pheochromocytoma, in this effect.

\section{Methods}

\section{Pheochromocytoma samples}

Tumor specimens were obtained from 25 patients with pheochromocytoma (see clinical characteristics of these patients in Supplementary Table 1, see section on supplementary data given at the end of this article). Malignancy was established in nine patients according to metastasis evidence. The diagnosis of benign tumor was assessed on the basis of the absence of metastasis during a followup of at least 2 years. Screening for mutations in susceptibility genes has been performed as described previously (Thouennon et al. 2007). Twenty patients were without evidence of a hereditary disease, i.e. sporadic tumors, while two patients had malignant tumors with an $S D H B$ mutation, two patients had benign tumors with a NF1 mutation, and one patient had a benign tumor with a RET mutation (MEN2). Among the benign tumors, 14 were located in the adrenal and 2 were at an extra-adrenal site. Among the malignant tumors, five were primarily located in the adrenal, two at an extra-adrenal site, and two corresponded to metastatic tissue. Tumor samples were provided by the Rouen University Hospital Center, the Nancy University Hospital Center, and the French network for collection of adrenal tumors (COMETE-3 network, PHRC AOM 06179). Written informed consent was obtained from each patient, and the protocol of collection of the samples was approved by the regional bioethics committees (Comite Consultatif de Protection des Personnes dans la Recherche Biomédicale de Haute-Normandie et de Paris, France). After removal, tumor samples were dissected, immediately frozen, and stored in liquid nitrogen until RNA or protein extraction.

\section{RNA extraction and quantitative real-time PCR}

Total RNA from tumor samples and PC12 cells was extracted using the Tri-Reagent (Sigma-Aldrich) according to the manufacturer's recommendations, and treated by the RQ1 RNase-free DNase (Promega). Before use, each sample was further purified on RNeasy mini Spin Columns (Qiagen) and quantified by spectrophotometry. One microgram of each cleaned total RNA sample was reverse-transcribed for $1 \mathrm{~h}$ at $52{ }^{\circ} \mathrm{C}$ with the ImProm-II Reverse Transcriptase (Promega) using random hexamers, $\mathrm{MgCl}_{2}$, dNTPs, and RNasin in the buffer supplied by the manufacturer (Promega). PCR amplification was carried out in the presence of $12.5 \mathrm{ng}$ of cDNA template, $6.25 \mu \mathrm{l}$ of SYBR Green I Master Mix Buffer (Applied Biosystems, Courtaboeuf, France), and 300, 600, or $900 \mathrm{nM}$ of forward and reverse primers, depending on the gene studied (see primer sequences used for quantitative PCR (qPCR) in Supplementary Table 2, see section on supplementary data given at the end of this article), in a $12.5 \mu \mathrm{l}$ volume, in an ABI PRISM 7000 Sequence Detector (Applied Biosystems). The cycling conditions comprised 10 min polymerase activation at $95^{\circ} \mathrm{C}$ and 40 cycles of DNA synthesis at $95^{\circ} \mathrm{C}$ for $15 \mathrm{~s}$ and $60^{\circ} \mathrm{C}$ for $1 \mathrm{~min}$. PCR efficiency was above $97 \%$ for all genes studied. In order to normalize qPCR results, we used four reference genes. The expression stability of the reference genes in our tumor series was verified using qBASE software, which also permitted correction of PCR efficiency differences, inter-run calibration, and multiple reference gene normalization (Vandesompele et al. 2002). Expression levels of the genes of interest are presented as percent of the mean expression of reference genes (RF) in each tumor. 


\section{Peptide extraction and AM RIA}

Frozen pheochromocytoma samples were boiled for $10 \mathrm{~min}$ in $0.5 \mathrm{M}$ acetic acid, homogenized in a glass Potter, sonicated, and centrifuged $\left(3000 \mathrm{~g}\right.$ at $\left.4{ }^{\circ} \mathrm{C}\right)$ for $30 \mathrm{~min}$. The pellets were used for the measurement of protein concentrations by the Bradford method. The supernatants were collected and loaded onto a Sep-Pak C18 cartridge (Waters Corp., St-Quentin en Yvelines, France) equilibrated with a solution of $0.1 \%$ trifluoroacetic acid (TFA) in water. Bound material was eluted from the cartridge with acetonitrile/water/TFA (59.9:40:0.1, vol/vol/vol) and dried by vacuum centrifugation material (Speed-Vac Concentrator, Savant AES 2000, Hicksville, NY, USA). The resulting pellets were resuspended in RIA buffer. The RIA of AM was performed as reported previously using the antiserum against human amidated AM 1-52 obtained from the Peptide Institute (Osaka, Japan) which was used at a final dilution of 1:30 000 (Rocchi et al. 2001).

\section{Western blot analysis}

Pheochromocytoma samples from five benign and four malignant tumors were homogenized in $10 \mathrm{mM}$ Tris- $\mathrm{HCl}(\mathrm{pH}$ 7.4) containing $0.05 \%$ Triton $\mathrm{X}-100$ and $1 \mathrm{mM}$ phenylmethylsulfonyl fluoride. After centrifugation $\left(21000 \mathrm{~g}\right.$ at $\left.4{ }^{\circ} \mathrm{C}\right)$ for $15 \mathrm{~min}$, the proteins contained in the supernatants were analyzed by western blot as previously described (Yon et al. 2003). Antibodies against PAM (El Meskini et al. 1997) and actin (Santa Cruz Biotechnology, Inc., Heidelberg, Germany) were used. Immunoreactivity was detected through a chemiluminescence detection kit (Amersham Pharmacia Biotech).

\section{Cell culture and treatment}

Two human pheochromocytomas were resected from patients admitted at the Rouen Hospital. No evidence of metastatic lesions was observed in these patients. Pheochromocytoma fragments were immersed in culture medium containing 50\% DMEM (SigmaAldrich) and 50\% F12 (Sigma-Aldrich). Tissues were minced with scissors, and tumor cells were enzymatically dispersed in culture medium containing $0.1 \%$ collagenase (Serlabo, Bonneuil-sur-Marne, France) and $30 \mathrm{U} / \mathrm{ml}$ DNase I (Sigma-Aldrich). Isolated cells were cultured in medium supplemented with 5\% fetal bovine serum (Invitrogen), $1 \%$ L-glutamine, $100 \mathrm{U} / \mathrm{ml}$ penicillin, $100 \mu \mathrm{g} / \mathrm{ml}$ streptomycin, and $0.25 \mu \mathrm{g} / \mathrm{ml}$ amphotericin B (SigmaAldrich) in $5 \% \mathrm{CO}_{2} / 95 \% \mathrm{O}_{2}$ humidified atmosphere at $37^{\circ} \mathrm{C}$. Cell treatments were performed after $24 \mathrm{~h}$ of culture. Rat pheochromocytoma-derived PC12 cells were purchased from the European Collection of Cell Culture (Salisbury, Wilshire, UK). PC12 cells were cultured in DMEM (Sigma-Aldrich) supplemented with $10 \%$ horse serum (Invitrogen), 5\% fetal bovine serum (Invitrogen), 1\% L-glutamine, $100 \mathrm{U} / \mathrm{ml}$ penicillin, and $100 \mu \mathrm{g} / \mathrm{ml}$ streptomycin (Sigma-Aldrich) at $37^{\circ} \mathrm{C}$ in a humidified atmosphere of $5 \% \mathrm{CO}_{2}$.

Human pheochromocytoma cells and PC12 cells were treated with $200 \mathrm{nmol} / \mathrm{l} \mathrm{AM}$ (Bachem AG, Bubendorf, Switzerland) or $50 \mathrm{ng} / \mathrm{ml} \mathrm{SDF1} \mathrm{(Peprotech}$ $\mathrm{EC}$, London, UK) for $48 \mathrm{~h}$.

\section{Immunocytochemical staining}

Cells were grown on slides and treated with peptides of interest. After treatment, cells were fixed with $4 \%$ paraformaldehyde and immunolabeled with rabbit antichromogranin A (CgA) antibody (Montero-Hadjadje et al. 2002). Cells were then incubated with Alexa Fluor 488-conjugated goat anti-rabbit IgG (Amersham Pharmacia Biotech) and 4',6'-diamidino-2-phenylindole (DAPI) (Sigma-Aldrich). Slides were observed with a Leica SP2 upright confocal laser scanning microscope (Leica Corp., Heidelberg, Germany) equipped with the Acoustico-Optico Beam Splitter system (Leica Corp). For each condition, 20 pictures were taken randomly in the slide. The number of total cells was determined on each slide by counting nuclei stained with DAPI. The number of chromaffin cells was determined by counting cells stained with $\mathrm{CgA}$.

\section{Determination of viable cell number by MTT assay}

Viable cell number was assessed using the 3-(4,5-dimethylthiazol-2-yl)-2,5-diphenyltetrazolium bromide (MTT) assay which is based on the cellular conversion of a tetrazolium salt into an insoluble purple formazan product in living cells. Cells cultured in $100 \mu \mathrm{l}$ of medium in 96-well culture plates were incubated with $10 \mu \mathrm{l}$ of PBS containing $5 \mathrm{mg} / \mathrm{ml}$ MTT for $3 \mathrm{~h}$ in $5 \% \mathrm{CO}_{2} / 95 \% \mathrm{O}_{2}$ humidified atmosphere at $37{ }^{\circ} \mathrm{C}$. Then, $100 \mu \mathrm{l}$ of the solubilization solution made up of $50 \% \mathrm{~N}, \mathrm{~N}$-dimethylformamide and $20 \%$ SDS, pH 4.7, were added to the culture medium, and the plates were incubated at $37^{\circ} \mathrm{C}$ overnight. The absorbance was then recorded using a microplate reader Bio-tek FL 600 (Bio-tek, Illkirsh, France). Specific optical density ( $\Delta$ OD750-570) for the MTT product was obtained by subtracting the OD value at $570 \mathrm{~nm}$ from that at $750 \mathrm{~nm}$, and reflects the number of viable cells. 


\section{siRNA experiments}

Transfection of siRNA in PC12 cells was performed with the Amaxa Nucleofector (Amaxa, Koeln, Germany) according to the instructions of the manufacturer. Approximately, $2 \times 10^{6}$ cells were resuspended into $100 \mu \mathrm{l}$ of Nucleofector solution containing $30 \mathrm{pmol}$ siRNA directed against RDC1 (Qiagen). Immediately after electroporation, fresh medium was added, and cells were cultured in 5\%

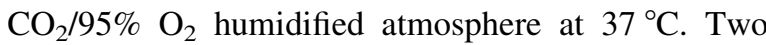
different siRNAs were used for inhibition of $R D C 1$ gene expression. Control cells were transfected with random siRNA (Qiagen).

\section{Measurement of caspase-3 activity}

PC12 cells were grown in 96-well plates and treated by SDF1 or AM. After $48 \mathrm{~h}$, cells were incubated with the fluorometric caspase-3 assay reagent (Promega). Fluorescence was then measured over a 6 -h period on a microplate reader Flexstation II (Molecular Devices Corporation, Sunnyvale, CA, USA).

\section{Statistical analysis}

Data are reported as median with range values (minimum-maximum). Comparison of gene expression between benign and malignant pheochromocytomas was performed using the non-parametric Mann-Whitney $U$ test. Two-way ANOVA was used to compare results obtained from different experiments. Probability values $<0.05$ were considered significant. Data were analyzed using the Prism program (GraphPad Software, Inc., San Diego, CA, USA).

\section{Results}

\section{Characterization of PAM mRNA and protein levels in benign and malignant pheochromocytomas}

The expression levels of the peptide-amidating enzyme PAM were analyzed in benign and malignant pheochromocytomas (Fig. 1 and Table 1). Median PAM gene expression was significantly higher in benign compared to malignant pheochromocytomas (Fig. 1A and Table 1). In order to determine the PAM protein levels, we performed western blot analysis of five benign and four malignant pheochromocytoma tissues. As observed for the mRNA, the PAM protein levels were lower in malignant compared to benign pheochromocytomas (Fig. 1B). These data confirm and

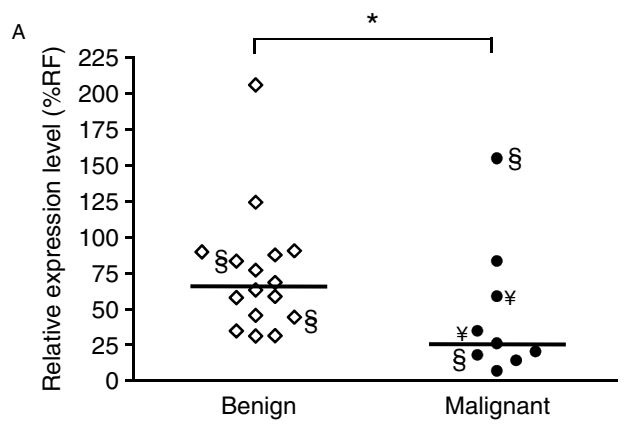

B

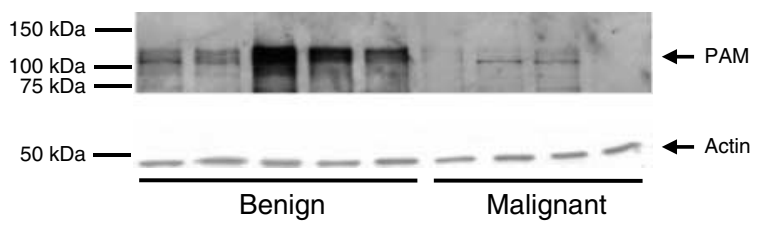

Figure 1 Measurement of the mRNA and protein levels of PAM in benign and malignant pheochromocytomas. (A) PAM mRNA levels were quantified in benign and malignant pheochromocytomas using qPCR as described in Methods. Data are presented as percent of the mean expression of reference genes (\%RF). The bars represent the median values. §, ectopic tumors; $¥$, metastasis. ${ }^{*} P<0.05$. (B) Western blot analysis from SDS-PAGE (12\%) with an ECL detection system showing proteins immunoreactive with PAM and $\beta$-actin-specific antibodies. Proteins were extracted from five benign and four malignant pheochromocytomas. Ten micrograms of proteins were loaded in each well for PAM and $\beta$-actin detection. A protein of $\sim 110 \mathrm{kDa}$ corresponding to the PAM protein was detected.

extend our previous microarray results showing that $P A M$ expression is reduced in malignant versus benign pheochromocytomas.

\section{Characterization of PACAP, PAC1-R, VPAC1-R, and VPAC2-R expression in benign and malignant pheochromocytomas}

We used qPCR in order to determine the mRNA levels of $P A C A P$ and its receptors PACl, VPACl, and $V P A C 2$ in a set of 16 benign and 9 malignant pheochromocytomas (Fig. 2 and Table 1). PACAP gene expression was detected in 15 of the 16 benign tumors and in all malignant pheochromocytomas (Fig. 2A). Median expression of PACAP was lower in malignant compared to benign tumors, although no significant differential expression was observed between the two tumor subtypes (Table 1). The expression of PAC1-R was detected in all tumors with no difference between benign and malignant pheochromocytomas (Fig. 2B and Table 1). The expression of $P A C 1-R$ in all pheochromocytomas was much higher than that of VPAC receptors. 
Table 1 Expression levels of the peptidylglycine $\alpha$-amidating monooxygenase (PAM) enzyme, pituitary adenylate cyclase-activating polypeptide (PACAP), neuropeptide Y (NPY), and adrenomedullin (AM) peptides, their receptors, and associated proteins in benign and malignant pheochromocytomas

\begin{tabular}{|c|c|c|c|c|c|}
\hline & \multicolumn{2}{|c|}{ Benign tumors } & \multicolumn{2}{|c|}{ Malignant tumors } & \multirow[b]{2}{*}{$P$ value } \\
\hline & Median (\%RF) & Range (\%RF) & Median (\%RF) & Range (\%RF) & \\
\hline PAM & 65.57 & 30.78-206.16 & 25.13 & $6.13-154.36$ & $0.0293^{*}$ \\
\hline PACAP & 5.82 & $0.00-51.76$ & 0.46 & $0.02-37.53$ & 0.7555 \\
\hline PAC1-R & 9.48 & $0.03-55.96$ & 15.15 & $1.15-66.55$ & 0.2697 \\
\hline VPAC1-R & 0.06 & $0.00-1.63$ & 0.00 & $0.00-0.97$ & 0.9772 \\
\hline VPAC2-R & 0.12 & $0.00-2.55$ & 0.16 & $0.00-45.26$ & 0.3956 \\
\hline NPY & 810.97 & $0.34-11829.54$ & 114.77 & $1.11-864.13$ & 0.1655 \\
\hline Y1 & 0.557 & $0.03-18.33$ & 0.37 & $0.04-6.80$ & 0.5522 \\
\hline Y2 & 0.14 & $0.00-6.20$ & 0.06 & $0.00-4.06$ & 0.3801 \\
\hline Y3/CXCR4 & 2.04 & $0.66-56.11$ & 1.85 & $0.53-8.88$ & 0.7989 \\
\hline Y4 & 0.13 & $0.00-1.59$ & 0.13 & $0.01-8.38$ & 0.6919 \\
\hline Y5 & 0.18 & $0.02-1.52$ & 0.10 & $0.05-3.61$ & 0.9323 \\
\hline AM & 10.78 & $0.30-21.95$ & 12.79 & $1.70-22.88$ & 0.5907 \\
\hline ADMR & 0.14 & $0.01-1.57$ & 0.35 & $0.06-53.08$ & 0.1655 \\
\hline CRLR & 0.33 & $0.07-2.26$ & 0.42 & $0.07-1.67$ & 0.4860 \\
\hline RDC1 & 7.10 & $0.48-29.80$ & 29.3 & $5.92-93.47$ & $0.0085^{\dagger}$ \\
\hline RAMP1 & 29.61 & $0.32-100.96$ & 14.52 & $5.51-33.16$ & 0.7024 \\
\hline RAMP2 & 2.36 & $0.35-21.06$ & 3.78 & $1.18-7.19$ & 0.4075 \\
\hline RAMP3 & 2.51 & $0.67-7.79$ & 6.83 & $1.46-20.80$ & 0.0997 \\
\hline
\end{tabular}

$\% \mathrm{RF}$, percent of the mean expression of reference genes; ${ }^{*} P<0.05 ;{ }^{\dagger} P<0.01$.

Indeed, $V P A C 1-R$ and $V P A C 2-R$ were detected in 50 and $62.5 \%$ of benign tumors respectively. In malignant tumors, VPAC1-R and VPAC2-R expression was detected in 45 and $89 \%$ of samples respectively. No significant differential expression was observed between benign and malignant pheochromocytomas for neither VPAC1-R nor VPAC2-R (Table 1). VPAC1-R and $V P A C 2-R$ expression was very weak in all tumors analyzed, representing $<3 \%$ of the expression of reference genes, except for one tumor where VPAC2-R mRNA level reached $45.26 \%$.

\section{Characterization of NPY, Y1, Y2, Y3/CXCR4, Y4, and $Y 5$ expression in benign and malignant pheochromocytomas}

We measured the expression levels of $N P Y$ and its $Y 1$, $Y 2, Y 4, Y 5$, and $Y 3 / C X C R 4$ receptors in benign and malignant pheochromocytomas (Fig. 3 and Table 1). NPY median expression level was $811 \%$ (range: $0.34-11830 \%$ ) in benign pheochromocytomas and $114.8 \%$ in malignant tumors. Although NPY median expression was approximately sevenfold lower in malignant tumors, no significant differential expression between the two tumor subtypes was found $(P=0.1655)$. Compared to PACAP, NPY expression was very high in all tumors analyzed (Fig. 3A and Table 1). All pheochromocytomas expressed the different NPY receptors except three and one that did not express
Y2 and Y4 respectively (Fig. 3B). However, median expression of $Y 1, Y 2, Y 4$, and $Y 5$ was very weak, and was lower than $1 \%$ of the expression of reference genes in $73 \%$ of cases. The expression level of Y3/CXCR4 receptor was much higher than that of reference genes in most tumors. No significant differential expression between benign and malignant pheochromocytomas was observed for $Y 1, Y 2, Y 3 / C X C R 4, Y 4$, and $Y 5$ (Fig. 3B and Table 1).

\section{Characterization of $A M, A D M R, C R L R$, RAMP1, $R A M P 2, R A M P 3$, and $R D C 1$ expression, and quantitation of amidated AM peptide levels in benign and malignant pheochromocytomas}

QPCR was also applied to determine $A M$ precursor mRNA levels in pheochromocytomas in comparison to reference gene expression (Fig. 4A and Table 1). The expression of $A M$ was detected in all tumors (Fig. 4A), but the mRNA levels did not vary between benign and malignant pheochromocytomas (Table 1). Using a specific RIA, we measured the amounts of amidated AM peptide in a group of ten benign and seven malignant pheochromocytomas. The concentrations of AM measured (Fig. 4B) were in the range of those reported for pheochromocytomas in other studies. Although the median value of AM concentration was higher in benign compared to malignant tumors $(0.55 \mathrm{pg} / \mu \mathrm{g}$ of protein for benign and $0.13 \mathrm{pg} / \mu \mathrm{g}$ of 

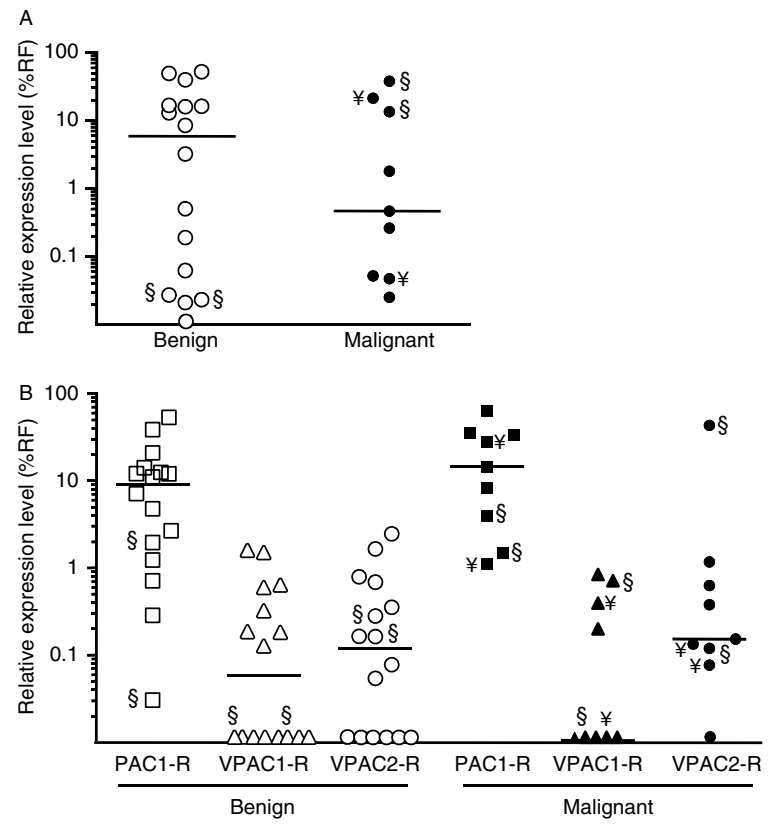

Figure 2 Quantification of PACAP, PAC1-R, VPAC1-R, and VPAC2-R expression in benign and malignant pheochromocytomas. (A) Scattergram of PACAP mRNA levels in benign and malignant pheochromocytomas. (B) Scattergram of $P A C A P$ receptor mRNA levels in benign and malignant pheochromocytomas. Data obtained by qPCR are presented as percent of the mean expression of reference genes (\%RF). The bars represent the median value for each group. $\S$, ectopic tumors; $¥$, metastasis.

protein for malignant tumors), no significant difference in amidated $\mathrm{AM}$ quantities was observed between the two tumor subtypes (Fig. 4B).

We assessed the expression levels of $C R L R, A D M R$, and $R D C 1$ receptors (Fig. $5 \mathrm{~A}$ and Table 1). Median $C R L R$ and $A D M R$ expression levels were very low in benign and malignant tumors, representing $<1 \%$ of the expression levels of reference genes in most samples (Table 1). No differential expression was observed for $C R L R$ and $A D M R$ genes between the two tumor subtypes (Table 1). Median RDCl expression levels relative to reference gene levels were respectively 47- and 63-fold higher than those of $C R L R$ and $A D M R$. Median $R D C 1$ expression levels were significantly lower in benign compared to malignant pheochromocytomas $(P=0.0085$; Table 1$)$.

We also assessed the expression of $C R L R$-associated proteins RAMP1, RAMP2, and RAMP3 which increase the affinity of this receptor toward AM or CGRP peptides (Fig. 5B and Table 1). Data showed expression of RAMP1, RAMP2, and RAMP3 genes in all pheochromocytomas analyzed (Fig. 5B). Median mRNA levels of $R A M P 2$ and $R A M P 3$ represented $2-7 \%$ of the expression of reference genes (Table 1).
Median expression levels of $R A M P 1$ were 2- to 12 -fold higher than those of $R A M P 2$ and $R A M P 3$ (Table 1). No differential expression between the two tumor subtypes was observed for RAMP1, RAMP2, and RAMP3 genes (Table 1).

\section{Effect of AM and SDF1 on human pheochromo- cytoma cells in primary culture}

In order to determine the effect of an amidated peptide on human pheochromocytoma, we treated two different primary cultures of human pheochromocytoma cells with AM $(200 \mathrm{nmol} / \mathrm{l})$ for 2 days. AM significantly increased the number of cells after $48 \mathrm{~h}$ of treatment, as revealed by an MTT assay (Fig. 6A; $P<0.01$ ). Because $R D C 1$ was highly expressed in pheochromocytoma compared to the other $\mathrm{AM}$ receptors and since $\mathrm{RDC} 1$ is also activated by SDF1, we assessed the effect of this chemokine on human pheochromocytoma cell number in culture. Like AM, SDF1 $(50 \mathrm{ng} / \mathrm{ml})$ also increased the number of pheochromocytoma cells after 2 days of treatment (Fig. 6A; $P<0.01$ ). In order to define the type of cells whose number increased after treatment, we determined the number of $\mathrm{CgA}$-labeled cells in treated or untreated conditions (Fig. 6B and C). Quantification

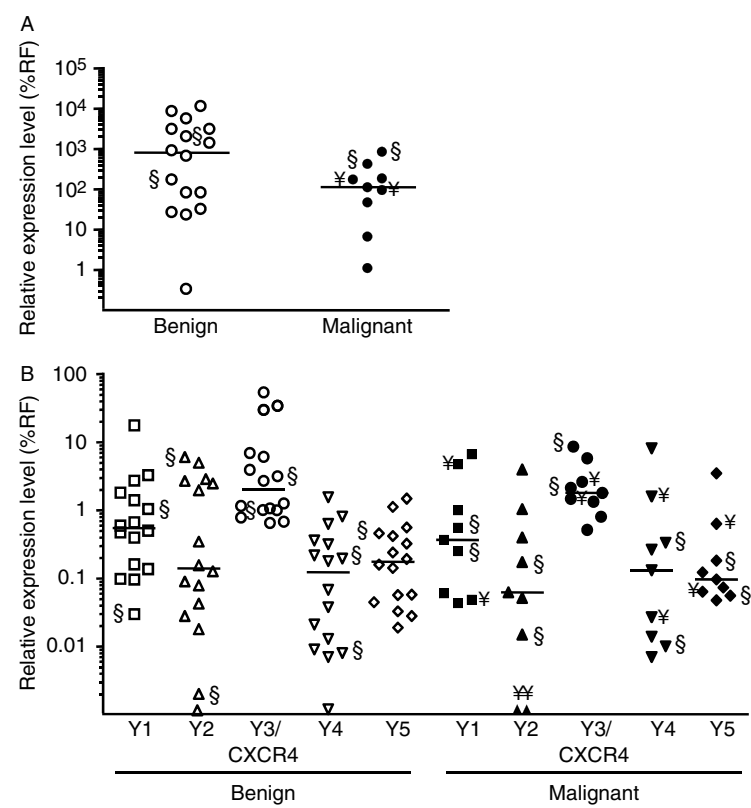

Figure 3 Quantification of the expression levels of NPY and NPY receptors $Y 1, Y 2, Y 3 / C X C R 4, Y 4$, and $Y 5$ in benign and malignant pheochromocytomas. (A) Scattergram of NPY mRNA levels in benign and malignant pheochromocytomas. (B) Scattergram of NPY receptor mRNA levels in benign and malignant pheochromocytomas. Data obtained by qPCR are presented as percent of the mean expression of reference genes (\%RF). The bars represent the median value for each group. §, ectopic tumors; $¥$, metastasis. 
A
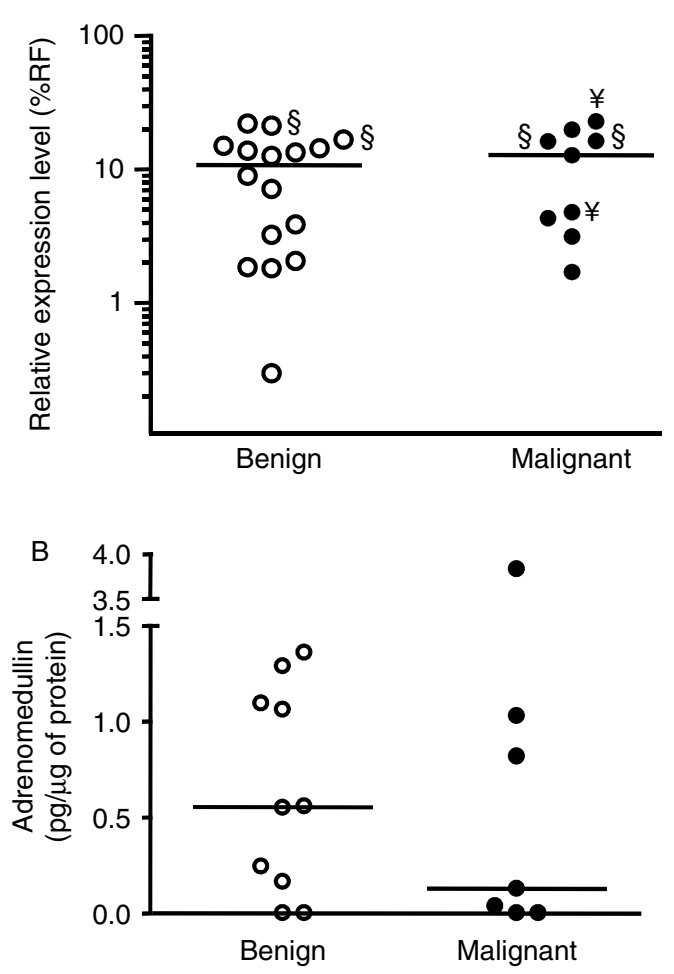

Figure 4 Quantification of AM mRNA and peptide levels in benign and malignant pheochromocytomas. (A) Scattergram of $A M \mathrm{mRNA}$ levels in benign and malignant pheochromocytomas. Data obtained by qPCR are presented as percent of the mean expression of reference genes (\%RF). (B) AM peptide concentrations in benign and malignant pheochromocytomas were assessed by RIA as described in Methods. The bars represent the median value for each group. $\S$, ectopic tumors; $¥$, metastasis.

of $\mathrm{CgA}$-stained cells showed a clear increase of tumoral chromaffin cells in the presence of AM, whereas SDF1 may act more globally on all cells in culture.

In order to confirm the high expression of $R D C l$ in pheochromocytoma tissues used for cell culture as was observed in the previous analysis (Fig. 5A), we measured by qPCR the expression of the various $A M$ receptor mRNAs in the two tumors. Among the three transcripts, the one encoding RDC1 exhibited by far the highest expression in both tumors (Fig. 6D). Similarly, RAMP1 proteins were expressed at high levels in the two tumors, followed by RAMP2 and finally RAMP3 whose expression levels were rather low (Fig. 6D).

\section{Effect of AM and SDF1 on rat pheochromocytoma PC12 cells}

In order to better understand the effects of AM and SDF1 in pheochromocytoma cells, we used the rat pheochromocytoma-derived PC12 cell line which also express $R D C 1$ gene (data not shown) as a cell model. After a 48-h treatment of PC12 cells with AM $(200 \mathrm{nmol} / \mathrm{l})$ or SDF1 $(50 \mathrm{ng} / \mathrm{ml})$, we observed a significantly higher number of cells in comparison to control condition (Fig. 7A). We then investigated whether AM and SDF1 could exert anti-apoptotic effects in PC12 cells. We showed that treatment of PC12 cells with AM or SDF1 resulted in a significant decrease in caspase activity (Fig. 7B). A pro-survival effect of AM and SDF1 was confirmed since both factors increased the number of living cells after serum deprivation (Fig. 7C).

\section{Effect of $R D C 1$ suppression on PC12 cell survival}

$R D C 1$ expression in PC12 cells was reduced by $80 \%$ using two different siRNAs, in comparison to control condition where a random siRNA was used (Fig. 8A). Transfection of PC12 cells by one or the other of these two siRNAs provoked a significant decrease in the number of cells after 2 days (Fig. 8B), but did not modify the effect of AM $(200 \mathrm{nmol} / \mathrm{l})$ or SDF1 (50 ng/ml) on caspase activity (Fig. 8C and D).

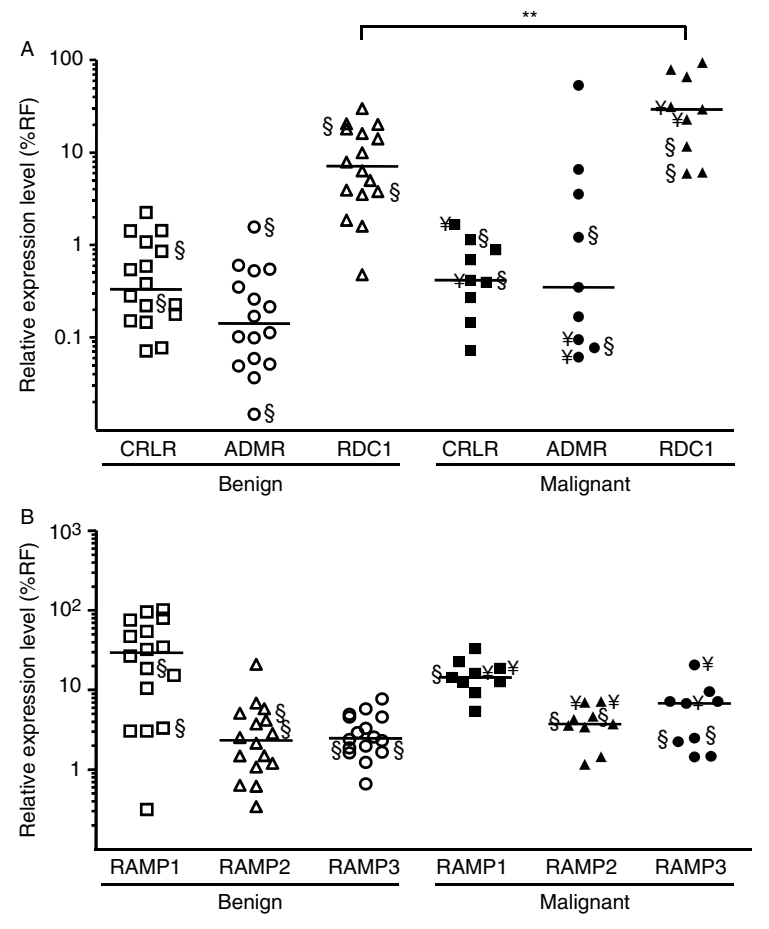

Figure 5 Quantification of the mRNA levels of $A M$ receptors $C R L R, A D M R$, and $R D C 1$ and the associated proteins RAMP1, RAMP2, and RAMP3 in benign and malignant pheochromocytomas. (A) Scattergram of $A M$ receptor mRNA levels in benign and malignant pheochromocytomas. (B) Scattergram of RAMP1, RAMP2, and RAMP3 mRNA levels in benign and malignant pheochromocytomas. Data are presented as percent of the mean expression of reference genes (\%RF). The bars represent the median value for each group. ${ }^{\star \star} P<0.01$. $\S$, ectopic tumors; $¥$, metastasis. 

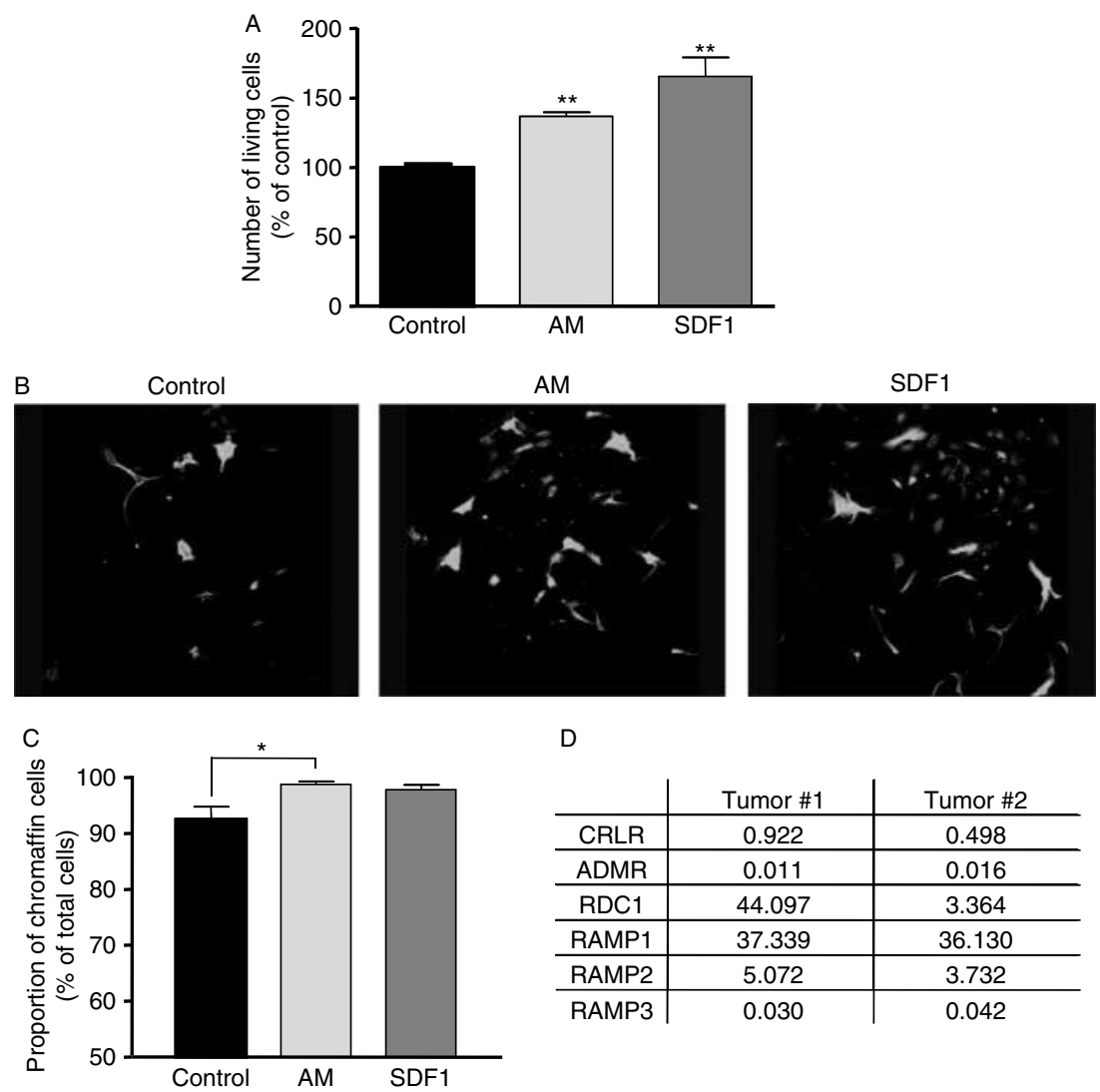

$\mathrm{D}$

\begin{tabular}{c|c|c} 
& Tumor \#1 & Tumor \#2 \\
\hline CRLR & 0.922 & 0.498 \\
\hline ADMR & 0.011 & 0.016 \\
\hline RDC1 & 44.097 & 3.364 \\
\hline RAMP1 & 37.339 & 36.130 \\
\hline RAMP2 & 5.072 & 3.732 \\
\hline RAMP3 & 0.030 & 0.042
\end{tabular}

Figure 6 Effects of AM and SDF1 in cultured human pheochromocytoma cells. (A) MTT assays were performed in order to assess the effect of AM $(200 \mathrm{nmol} / \mathrm{l})$ and SDF1 $(50 \mathrm{ng} / \mathrm{ml})$ on human pheochromocytoma cells in primary culture. Two separate cell culture experiments using different tumors were used, and yielded similar results. A representative experiment is shown. Each treatment was performed in ten replicates. (B) Immunocytochemistry performed after $48 \mathrm{~h}$ of culture in the presence or absence of AM or SDF1. Cells were immunostained with $\mathrm{CgA}$ in order to determine chromaffin cell proportion in the different conditions, and analyzed by confocal microscopy. (C) The proportion of chromaffin cells in the primary cultures was determined after CgA and DAPI staining. A representative experiment is shown. (D) Quantification by qPCR of the mRNA levels of AM receptors and associated proteins in the tumors used for primary cultures. Results are given in percent of the mean expression of reference genes. Error bars represent S.E.M. ${ }^{\star} P<0.05,{ }^{* *} P<0.01$ versus control.

\section{Discussion}

Among the main clinical challenges presented by pheochromocytoma, malignancy remains the most problematic aspect of this disease because of a lack of prognostic criteria and an effective therapeutic treatment. The observation that malignant tumors exhibit reduced expression of peptide-modifying enzymes such as glutaminyl cyclase, which catalyzes the addition of glutaminyl groups to the $\mathrm{N}$-terminus, and PAM enzyme, which introduces an amidated moiety to the C-terminus of bioactive peptides, suggested that the concentration and activity of trophic peptides may be altered during pheochromocytoma cell transformation (Thouennon et al. 2007). We confirmed in the present study that PAM expression is down-regulated not only at the mRNA level but also at the protein level as well in malignant compared to benign pheochromocytomas. In order to determine whether the variation in the expression of this enzyme could be associated with an alteration of peptide biosynthesis and receptor expression, we measured the mRNA levels of several trophic peptides such as PACAP, NPY, and AM, and their receptors in benign and malignant pheochromocytomas, and normalized the values obtained through the analysis of four reference genes in order to obtain reliable results. Among the benign and malignant tumors analyzed in this study, the location of the tumor, i.e. adrenal versus extra-adrenal, did not seem to impact on the peptide/ receptor expression levels. Similarly, among the nine malignant tumors studied here, the two metastatic tissues included did not modify the statistical 

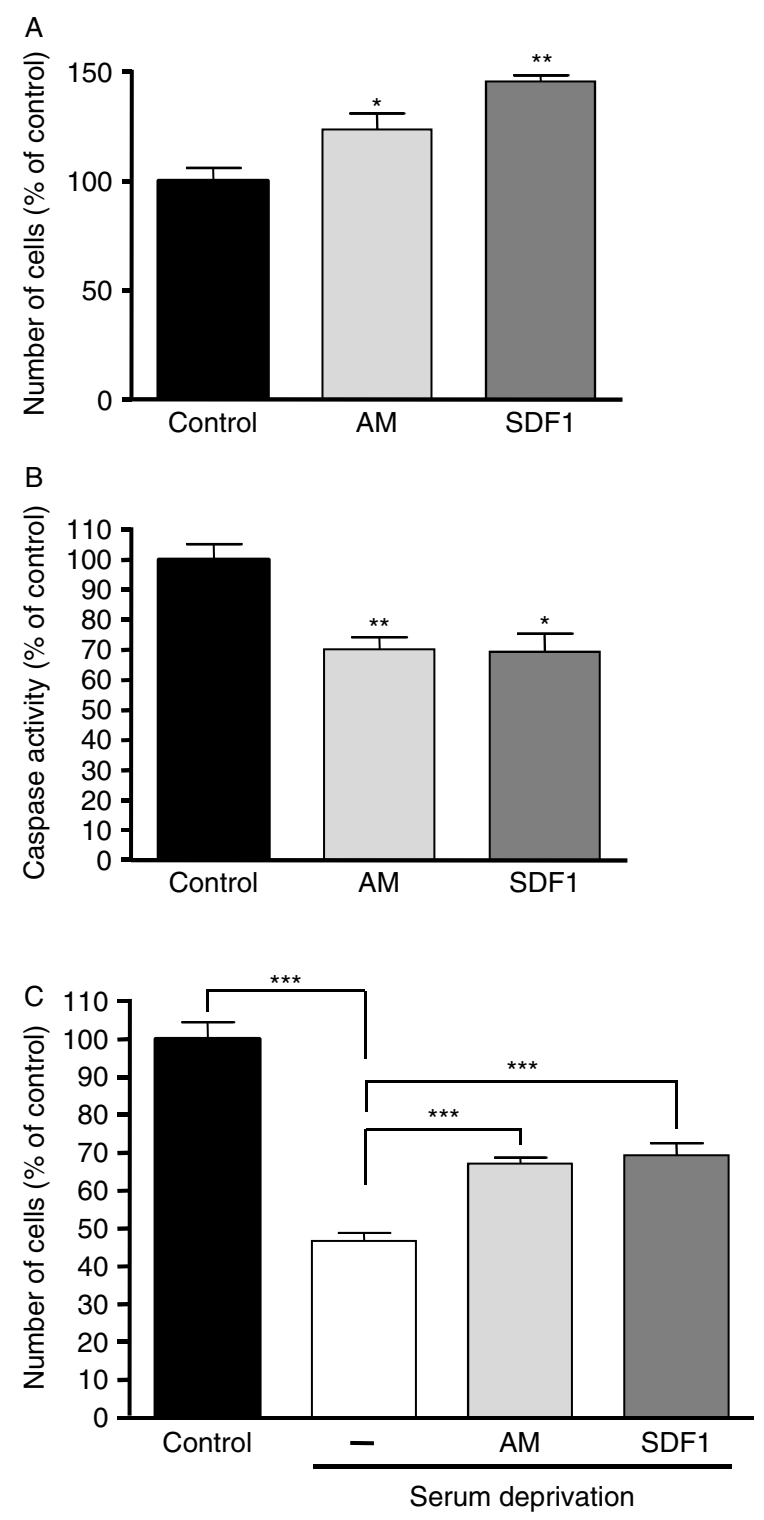

Figure 7 Effects of AM and SDF1 in PC12 cells. (A) Cell number was assessed after $48-\mathrm{h}$ treatment with $\mathrm{AM}(200 \mathrm{nmol} / \mathrm{l})$ and SDF1 (50 ng/ml). (B) Caspase activity measurement was performed in PC12 cells as described in Methods after a 48-h treatment with AM or SDF1. (C) Cell number was assessed after 48-h treatment of PC12 cells with $A M$ and SDF1 under serum-deprived condition. ${ }^{\star} P<0.05 ;{ }^{\star \star} P<0.01 ;{ }^{* \star \star} P<0.001$ versus control. Error bars represent S.E.M.

significance of the data obtained. Therefore, we have only considered in the present study the comparisons between benign and malignant tumor groups because the other subpopulations were not large enough to be analyzed separately.

We observed that PACAP is expressed, at varying levels, in almost all tumors, and only one benign neoplasia did not express this mRNA. It has been suggested that VPAC1-R would be the predominant PACAP receptor in pheochromocytomas (Isobe et al. 2003); however, we found that the transcript of this receptor could be detected in only 50 and $45 \%$ of benign and malignant tumors in our tumor series respectively. The VPAC2-R mRNA was present in more tumors since it was amplified in 62.5 and $89 \%$ of benign and malignant neoplasms respectively. By contrast, $P A C 1-R$ expression was detected in all tumors analyzed, and its mRNA levels were $\sim 20$-fold higher than those of VPAC1-R and VPAC2-R, suggesting that PAC1-R would be the predominant receptor for an autocrine effect of PACAP in pheochromocytoma. Accordingly, PAC1-R has been shown to mediate the effect of PACAP on catecholamine secretion in normal and tumoral sympathetic neurons (Taupenot et al. 1998, Ghzili et al. 2008). In addition, the prodifferentiating effects of PACAP are mediated through PAC1-R (Grumolato et al. 2003b). Therefore, PACAP and its PACAP-preferring receptor PAC1-R are probably involved in the pathophysiology of pheochromocytoma. The fact that PACAP mRNA levels were lower in most malignant tumors compared to benign tumors, although statistical significance was not reached, indicates that a decrease in the expression of this gene may participate to malignant dedifferentiation of some pheochromocytomas.

Several reports have described the occurrence of NPY and its receptors in pheochromocytoma (Grouzmann et al. 2001, Korner et al. 2004, Kitlinska et al. 2005, Cleary et al. 2007), but no systematic survey of the expression of these genes has been performed so far in benign and malignant tumors. Thus, we measured by qPCR the mRNA levels of $N P Y$ and its five receptors in these tumors. The receptors $Y 1, Y 2, Y 3 / C X C R 4, Y 4$, and $Y 5$ were widely expressed in pheochromocytomas, since only 3 out of 25 tumors did not express $Y 2$ and only 1 tumor did not express $Y 4$. The expression levels of the five receptors were very low, representing $<1 \%$ of the mean expression of reference genes in $73 \%$ of the samples analyzed. In contrast, $N P Y$ mRNA was found to be highly expressed in all samples analyzed, at median values reaching $800 \%$ in benign pheochromocytomas and $100 \%$ in malignant tumors relative to values of reference genes. Owing to high variation among malignant pheochromocytomas, expression levels of $N P Y$ between the two types of tumors failed to be significantly different. Other studies showed higher $N P Y$ expression in benign than in malignant pheochromocytomas (Helman et al. 1989, deS Senanayake et al. 1995). Paradoxically, it has also been shown that patients with malignant pheochromocytomas exhibit higher plasma concentration of NPY 

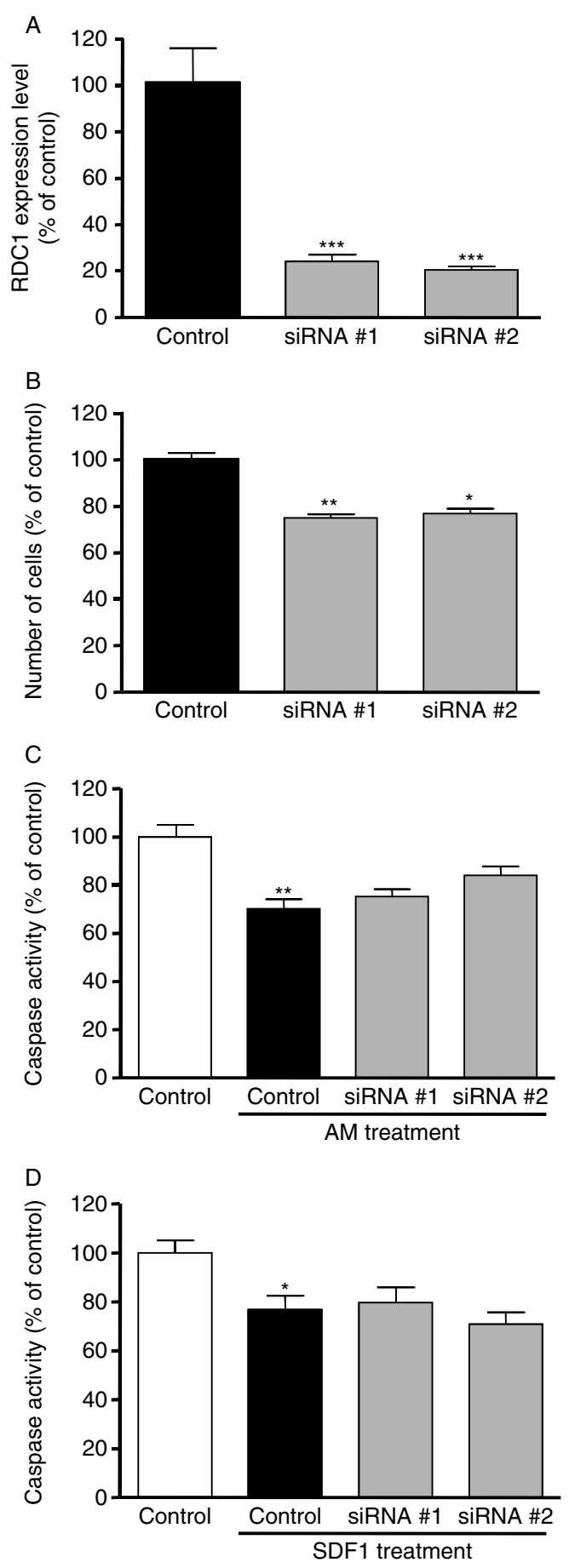

Figure 8 Effect of $R D C 1$ gene silencing in PC12 cells. (A) RDC1 gene expression levels were quantified by qPCR after transfection of PC12 cells by siRNAs. (B) Cell number was determined after transfection of PC12 cells with siRNAs directed against RDC1. (C) Caspase activity was measured after transfection of PC12 cells by siRNAs directed against $R D C 1$ gene and a 48-h treatment by AM. (D) Caspase activity was measured after transfection of PC12 cells by siRNAs directed against $R D C 1$ gene and a 48-h treatment with SDF1. ${ }^{\star} P<0.05 ;{ }^{\star \star} P<0.01 ;{ }^{\star \star \star} P<0.001$ versus control. Error bars represent S.E.M.
(Grouzmann et al. 1990). These conflicting results could be explained by the important differences of secretion between benign and malignant tumors and the heterogeneity of pheochromocytomas in general. The pathophysiological significance of the high expression levels of $N P Y$ is not known and warrants further investigation. NPY has been shown to stimulate catecholamine secretion from human chromaffin cells (Cavadas et al. 2001). The high expression of its gene in pheochromocytoma may participate to the excessive secretion of catecholamines observed in these tumors through an autocrine effect of the peptide. Because NPY failed to alter rat PC12 cell proliferation or apoptosis (Kitlinska et al. 2005), it is unlikely that this peptide participates to pheochromocytoma cell transformation.

Although AM has been initially isolated from pheochromocytoma, its role in this tumor has remained elusive. In the present study, we measured the expression levels of $A M$ and its $A D M R, C R L R$, and $R D C 1$ receptors in benign and malignant pheochromocytomas. Relatively low levels of $A M$ expression were observed in pheochromocytomas, representing about $10 \%$ of the mean expression levels of reference genes. No significant variation of $A M$ mRNA levels was found between benign and malignant tumors. Similarly, no significant change was observed in AM peptide concentrations in the two tumor subtypes.

Quantification of the gene expression of AM receptors in pheochromocytomas showed that $A D M R$ and $C R L R$ mRNA levels were low, representing $<1 \%$ of the expression levels of reference genes in about $80 \%$ of cases. Moreover, expression of $R A M P 1$, which is associated with CRLR receptor to ensure high affinity toward CGRP, was 2- to 12-fold higher than the expression levels of $R A M P 2$ and $R A M P 3$ which are associated with this receptor to provide high affinity toward AM. This result does not argue for a role of the CRLR receptor in the potential effect of AM in pheochromocytoma. Unlike the $A D M R$ and $C R L R$ which were weakly expressed, the mRNA levels of $R D C 1$ receptor represented about $10 \%$ of the expression levels of reference genes in benign pheochromocytomas and about $30 \%$ in malignant tumors. Together, these observations suggest that RDC1 could be the predominant receptor for an autocrine effect of AM in pheochromocytomas. Importantly, among all genes examined in benign and malignant pheochromocytomas, $R D C 1$ was the only one that exhibited a significant differential expression between the two tumor subtypes, suggesting that this receptor could be involved in malignant transformation of pheochromocytoma cells. 
It should be noted that this differential expression was also observed when only primary malignant tumors were considered.

The receptor RDC1 was simultaneously described as a receptor for AM/CGRP and the chemokine SDF1, and was also named CXCR7 in accordance with the nomenclature of CXCRs (Balabanian et al. 2005). Such a situation has also been reported for the NPY receptor Y3/CXCR4 which has been described also as a receptor for SDF1 (Bleul et al. 1996). Interestingly, $\mathrm{AM}, \mathrm{NPY}$, and SDF1 are all implicated in angiogenesis, and may control this process during tumorigenesis through common receptors such as CXCRs (Ishikawa et al. 2003, Maderna et al. 2007). In particular, it has previously been shown that $R D C 1$ is overexpressed in hypoxia condition, in the vascular area of several tumors, and in some malignant tumors, suggesting that it could have an important role in tumoral neoangiogenesis and malignancy (Ladoux \& Frelin 2000, Madden et al. 2004, Bosco et al. 2006, Miao et al. 2007). Beside such a potential implication of RDC1 in angiogenesis, it has been shown that this receptor is involved in the proliferation and survival of several tumoral cell lines (Miao et al. 2007, Wang et al. 2008).

The study of the role of peptides and their receptors in the pathophysiology of pheochromocytoma could be approached through the use of primary cultures of tumoral samples. However, the scarcity of this tumor hampers in depth the studies on cultured human pheochromocytoma cells. During the present study, we had access to two benign tumors that we could use for cell culture in order to test the potential effect of $\mathrm{AM}$ and SDF1 on human pheochromocytoma cells. Both factors increased the number of cultured human pheochromocytoma cells after $48 \mathrm{~h}$ of treatment. Labeling with $\mathrm{CgA}$, a specific marker of chromaffin cells, showed that AM effectively increased the number of tumoral chromaffin cells in culture. At this stage, it is not possible to conclude whether AM and SDF1 act on cell proliferation or survival. However, since benign pheochromocytomas are devoid of proliferative activity, differences in cell number observed between untreated cells and cells treated with AM or SDF1 are most likely due to an effect of these peptides on survival of pheochromocytes. Characterization of AM receptors in the tumors used for cell culture revealed that the expression of $R D C 1$ was several-fold higher than that of CRLR and ADMR. Moreover, in both pheochromocytoma samples, $R A M P 1$, which gives to CRLR more affinity to CGRP, was much more highly expressed than $R A M P 2$ and RAMP3, suggesting that CRLR may not mediate the effect of AM in pheochromocytoma.
Together with the data obtained on $R D C 1$ expression in our set of 25 pheochromocytoma samples, these results suggest that RDC1 may represent the predominant receptor for an autocrine effect of AM in these tumors.

In the absence of a human model of this type of tumor, we used the rat $\mathrm{PC} 12$ cell line to further elucidate the involvement of AM/SDF1 and RDC1 in pheochromocytoma cell pathology. Despite its limitations, this cell line may help to understand the role of trophic factors in tumorigenesis of chromaffin cells (Grumolato et al. 2003a). We showed that both AM and SDF1 significantly increased the number of PC12 cells after a 2-day treatment, compared to untreated cells. Moreover, we observed that the two factors also decreased caspase activity and promoted survival of PC12 cells when cultured in serum-deprived medium. Together with the data obtained using human pheochromocytoma cells, these results indicate that AM and SDF1 exert protective effects on pheochromocytoma cells. To determine the role of RDC1 in the prosurvival effect exerted by AM and SDF1, we used specific siRNAs to silence its expression before treatment of PC12 cells with these peptides. Viable cell quantitation showed that down-regulation of the $R D C 1$ gene provokes a decrease in the number of cells, indicating that RDC1 is indeed involved in pheochromocytoma cell survival/proliferation. Cell cycle analyses indicated that RDC1 is probably not involved in PC12 cell proliferation (data not shown). In line with these data, $R D C l$ has been shown to be overexpressed in breast, prostate, or lung tumors, and to be associated with their malignant behavior (Miao et al. 2007, Wang et al. 2008). On the other hand, RDC1 siRNA transfection did not modify the effects of AM and SDF1 on caspase activity in PC12 cells. These results suggest that although RDC1 may be involved in PC12 cell survival, it does not seem to be implicated in the effect of AM and SDF1 in these cells. Because PC12 cells also express the other AM receptors at comparable levels than RDCl (data not shown), it is possible that AM may also use these receptors in this in vitro cell model. Therefore, the lack of effect of AM/SDF1 through RDC1 on PC12 cell survival does not preclude the recruitment of this receptor, which is highly expressed in human malignant pheochromocytomas, to mediate the effect on tumoral cell survival in vivo. Interestingly, in adrenal medulla and pheochromocytomas, chromaffin cells are closely associated with capillary endothelial cells. These cells can produce neo-angiogenic factors such as AM which could act in a paracrine manner on adjacent chromaffin cells and thus participate to the tumorigenic process, 
supporting the idea that endothelial cells play a supportive role for pheochromocytoma cells (Mizrachi et al. 1989).

In conclusion, we showed in the present study the widespread expression of several amidated trophic peptides and their various receptors in human pheochromocytoma, and we could demonstrate that AM increases the number of tumoral cells in primary cultures. We also identified for the first time the robust expression of the $\mathrm{AM}$ receptor $R D C 1$ in human pheochromocytoma and its higher expression in malignant tumors, suggesting that this receptor could be involved in chromaffin cell malignant tumorigenesis and in the effects of AM and SDF1 in these tumors. In a pheochromocytoma cell model, the PC12 cell line, we could confirm the pro-survival effect of AM and SDF1 on tumoral cells, although the mechanisms involved in these effects may differ between rat and human cells. Thus, the data reported in the present study may have interesting therapeutic implications since AM or RDC1 is currently investigated as therapeutic targets in other cancers including breast, lung, glial, and colon neoplasia (Rocchi et al. 2001, Miao et al. 2007, Kaafarani et al. 2009).

\section{Supplementary data}

This is linked to the online version of the paper at http://dx. doi.org/10.1677/ERC-10-0109.

\section{Declaration of interest}

The authors declare that there is no conflict of interest that could be perceived as prejudicing the impartiality of the research reported.

\section{Funding}

This work was supported by the Conseil Régional de HauteNormandie, IFRMP23, INSERM U982, University of Rouen, Ligue Nationale de Lutte Contre le Cancer, Association pour la Recherche sur le Cancer, and COMETE network (PHRC 06179).

\section{Acknowledgements}

The authors thank Huguette Lemonnier and Patrice Bizet for their technical assistance.

\section{References}

Balabanian K, Lagane B, Infantino S, Chow KY, Harriague J, Moepps B, Arenzana-Seisdedos F, Thelen M \&

Bachelerie F 2005 The chemokine SDF-1/CXCL12 binds to and signals through the orphan receptor RDC1 in T lymphocytes. Journal of Biological Chemistry 280 35760-35766.

Bleul CC, Farzan M, Choe H, Parolin C, Clark-Lewis I, Sodroski J \& Springer TA 1996 The lymphocyte chemoattractant SDF-1 is a ligand for LESTR/fusin and blocks HIV-1 entry. Nature 382 829-833.

Bosco MC, Puppo M, Santangelo C, Anfosso L, Pfeffer U, Fardin P, Battaglia F \& Varesio L 2006 Hypoxia modifies the transcriptome of primary human monocytes: modulation of novel immune-related genes and identification of CC-chemokine ligand 20 as a new hypoxia-inducible gene. Journal of Immunology 177 1941-1955.

Cavadas C, Silva AP, Mosimann F, Cotrim MD, Ribeiro CA, Brunner HR \& Grouzmann E 2001 NPY regulates catecholamine secretion from human adrenal chromaffin cells. Journal of Clinical Endocrinology and Metabolism 86 5956-5963.

Chrisoulidou A, Kaltsas G, Ilias I \& Grossman AB 2007 The diagnosis and management of malignant phaeochromocytoma and paraganglioma. Endocrine-Related Cancer 14 569-585.

Cleary S, Phillips JK, Huynh TT, Pacak K, Elkahloun AG, Barb J, Worrell RA, Goldstein DS \& Eisenhofer G 2007 Neuropeptide $\mathrm{Y}$ expression in phaeochromocytomas: relative absence in tumours from patients with von Hippel-Lindau syndrome. Journal of Endocrinology 193 225-233.

Conconi MT, Spinazzi R \& Nussdorfer GG 2006 Endogenous ligands of PACAP/VIP receptors in the autocrineparacrine regulation of the adrenal gland. International Reviews of Cytology 249 1-51.

Eisenhofer G, Bornstein SR, Brouwers FM, Cheung NK, Dahia PL, de Krijger RR, Giordano TJ, Greene LA, Goldstein DS, Lehnert H et al. 2004 Malignant pheochromocytoma: current status and initiatives for future progress. Endocrine-Related Cancer 11 423-436.

El Meskini R, Boudouresque F \& Ouafik L 1997 Estrogen regulation of peptidylglycine alpha-amidating monooxygenase messenger ribonucleic acid levels by a nuclear posttranscriptional event. Endocrinology 138 5256-5265.

Ghzili H, Grumolato L, Thouennon E, Tanguy Y, Turquier V, Vaudry H \& Anouar Y 2008 Role of PACAP in the physiology and pathology of the sympathoadrenal system. Frontiers in Neuroendocrinology 29 128-141.

Gimenez-Roqueplo AP, Burnichon N, Amar L, Favier J, Jeunemaitre X \& Plouin PF 2008 Recent advances in the genetics of phaeochromocytoma and functional paraganglioma. Clinical and Experimental Pharmacology \& Physiology 35 376-379.

Grouzmann E, Gicquel C, Plouin PF, Schlumberger M, Comoy E \& Bohuon C 1990 Neuropeptide Y and neuronspecific enolase levels in benign and malignant pheochromocytomas. Cancer 66 1833-1835.

Grouzmann E, Fathi M, Gillet M, de Torrente A, Cavadas C, Brunner H \& Buclin T 2001 Disappearance rate of 
catecholamines, total metanephrines, and neuropeptide $\mathrm{Y}$ from the plasma of patients after resection of pheochromocytoma. Clinical Chemistry 47 1075-1082.

Grumolato L, Elkahloun AG, Ghzili H, Alexandre D, Coulouarn C, Yon L, Salier JP, Eiden LE, Fournier A, Vaudry H et al. 2003 a Microarray and suppression subtractive hybridization analyses of gene expression in pheochromocytoma cells reveal pleiotropic effects of pituitary adenylate cyclase-activating polypeptide on cell proliferation, survival, and adhesion. Endocrinology 144 2368-2379.

Grumolato L, Louiset E, Alexandre D, Ait-Ali D, Turquier V, Fournier A, Fasolo A, Vaudry H \& Anouar Y 2003b PACAP and NGF regulate common and distinct traits of the sympathoadrenal lineage: effects on electrical properties, gene markers and transcription factors in differentiating PC12 cells. European Journal of Neuroscience 17 71-82.

Guillemot J, Ait-Ali D, Turquier V, Montero-Hadjadje M, Fournier A, Vaudry H, Anouar Y \& Yon L 2006 Involvement of multiple signaling pathways in PACAPinduced EM66 secretion from chromaffin cells. Regulatory Peptides 137 79-88.

Hansel DE, Eipper BA \& Ronnett GV 2001 Neuropeptide Y functions as a neuroproliferative factor. Nature $\mathbf{4 1 0}$ 940-944.

Hao HX, Khalimonchuk O, Schraders M, Dephoure N, Bayley JP, Kunst H, Devilee P, Cremers CW, Schiffman JD, Bentz BG et al. 2009 SDH5, a gene required for flavination of succinate dehydrogenase, is mutated in paraganglioma. Science 325 1139-1142.

Helman LJ, Cohen PS, Averbuch SD, Cooper MJ, Keiser HR \& Israel MA 1989 Neuropeptide Y expression distinguishes malignant from benign pheochromocytoma. Journal of Clinical Oncology 7 1720-1725.

Ichiki Y, Kitamura K, Kangawa K, Kawamoto M, Matsuo H \& Eto T 1994 Distribution and characterization of immunoreactive adrenomedullin in human tissue and plasma. FEBS Letters 338 6-10.

Ishikawa T, Chen J, Wang J, Okada F, Sugiyama T, Kobayashi T, Shindo M, Higashino F, Katoh H, Asaka M et al. 2003 Adrenomedullin antagonist suppresses in vivo growth of human pancreatic cancer cells in SCID mice by suppressing angiogenesis. Oncogene 22 1238-1242.

Isobe K, Tatsuno I, Yashiro T, Nanmoku T, Takekoshi K, Kawakami Y \& Nakai T 2003 Expression of mRNA for PACAP and its receptors in intra- and extra-adrenal human pheochromocytomas and their relationship to catecholamine synthesis. Regulatory Peptides 110 213-217.

Kaafarani I, Fernandez-Sauze S, Berenguer C, Chinot O, Delfino C, Dussert C, Metellus P, Boudouresque F, Mabrouk K, Grisoli F et al. 2009 Targeting adrenomedullin receptors with systemic delivery of neutralizing antibodies inhibits tumor angiogenesis and suppresses growth of human tumor xenografts in mice. FASEB Journal 23 3424-3435.
Kapas S \& Clark AJ 1995 Identification of an orphan receptor gene as a type 1 calcitonin gene-related peptide receptor. Biochemical and Biophysical Research Communications 217 832-838.

Kitamura K, Kangawa K, Kawamoto M, Ichiki Y, Nakamura S, Matsuo H \& Eto T 1993 Adrenomedullin: a novel hypotensive peptide isolated from human pheochromocytoma. Biochemical and Biophysical Research Communications 192 553-560.

Kitlinska J, Abe K, Kuo L, Pons J, Yu M, Li L, Tilan J, Everhart L, Lee EW, Zukowska Z et al. 2005 Differential effects of neuropeptide $\mathrm{Y}$ on the growth and vascularization of neural crest-derived tumors. Cancer Research 65 1719-1728.

Korner M, Waser B \& Reubi JC 2004 High expression of neuropeptide $\mathrm{Y}$ receptors in tumors of the human adrenal gland and extra-adrenal paraganglia. Clinical Cancer Research 10 8426-8433.

Ladoux A \& Frelin C 2000 Coordinated up-regulation by hypoxia of adrenomedullin and one of its putative receptors (RDC-1) in cells of the rat blood-brain barrier. Journal of Biological Chemistry 275 39914-39919.

Lee EW, Michalkiewicz M, Kitlinska J, Kalezic I, Switalska H, Yoo P, Sangkharat A, Ji H, Li L, Michalkiewicz T et al. 2003 Neuropeptide Y induces ischemic angiogenesis and restores function of ischemic skeletal muscles. Journal of Clinical Investigation 111 1853-1862.

Lenders JW, Eisenhofer G, Mannelli M \& Pacak K 2005 Phaeochromocytoma. Lancet 366 665-675.

Madden SL, Cook BP, Nacht M, Weber WD, Callahan MR, Jiang Y, Dufault MR, Zhang X, Zhang W, WalterYohrling J et al. 2004 Vascular gene expression in nonneoplastic and malignant brain. American Journal of Pathology 165 601-608.

Maderna E, Salmaggi A, Calatozzolo C, Limido L \& Pollo B 2007 Nestin, PDGFRbeta, CXCL12 and VEGF in glioma patients: different profiles of (pro-angiogenic) molecule expression are related with tumor grade and may provide prognostic information. Cancer Biology \& Therapy 6 1018-1024.

Manger WM 2006 Diagnosis and management of pheochromocytoma - recent advances and current concepts. Kidney International 70 S30-S35.

Mazzocchi G, Albertin G, Andreis PG, Neri G, Malendowicz LK, Champion HC, Bahcelioglu M, Kadowitz PJ \& Nussdorfer GG 1999 Distribution, functional role, and signaling mechanism of adrenomedullin receptors in the rat adrenal gland. Peptides 20 1479-1487.

McLatchie LM, Fraser NJ, Main MJ, Wise A, Brown J, Thompson N, Solari R, Lee MG \& Foord SM 1998 RAMPs regulate the transport and ligand specificity of the calcitonin-receptor-like receptor. Nature 393 333-339.

Miao Z, Luker KE, Summers BC, Berahovich R, Bhojani MS, Rehemtulla A, Kleer CG, Essner JJ, Nasevicius A, Luker GD et al. 2007 CXCR7 (RDC1) promotes breast and lung tumor growth in vivo and is expressed on tumor-associated vasculature. PNAS 104 15735-15740. 
Mizrachi Y, Lelkes PI, Ornberg RL, Goping G \& Pollard HB 1989 Specific adhesion between pheochromocytoma (PC12) cells and adrenal medullary endothelial cells in co-culture. Cell and Tissue Research 256 365-372.

Montero-Hadjadje M, Vaudry H, Turquier V, Leprince J, Do Rego JL, Yon L, Gallo-Payet N, Plouin PF \& Anouar Y 2002 Localization and characterization of evolutionarily conserved chromogranin A-derived peptides in the rat and human pituitary and adrenal glands. Cell and Tissue Research 310 223-236.

Nishikimi T 2007 Adrenomedullin in the kidney-renal physiological and pathophysiological roles. Current Medicinal Chemistry 14 1689-1699.

Pons J, Kitlinska J, Ji H, Lee EW \& Zukowska Z 2003 Mitogenic actions of neuropeptide $\mathrm{Y}$ in vascular smooth muscle cells: synergetic interactions with the betaadrenergic system. Canadian Journal of Physiology and Pharmacology 81 177-185.

Ribatti D, Conconi MT \& Nussdorfer GG 2007 Nonclassic endogenous novel [corrected] regulators of angiogenesis. Pharmacological Reviews 59 185-205.

Rocchi P, Boudouresque F, Zamora AJ, Muracciole X, Lechevallier E, Martin PM \& Ouafik L 2001 Expression of adrenomedullin and peptide amidation activity in human prostate cancer and in human prostate cancer cell lines. Cancer Research 61 1196-1206.

Rosmaninho-Salgado J, Araujo IM, Alvaro AR, Mendes AF, Ferreira L, Grouzmann E, Mota A, Duarte EP \& Cavadas C 2009 Regulation of catecholamine release and tyrosine hydroxylase in human adrenal chromaffin cells by interleukin-1beta: role of neuropeptide $\mathrm{Y}$ and nitric oxide. Journal of Neurochemistry 109 911-922.

deS Senanayake P, Denker J, Bravo EL \& Graham RM 1995 Production, characterization, and expression of neuropeptide Y by human pheochromocytoma. Journal of Clinical Investigation 96 2503-2509.

Taupenot L, Mahata SK, Wu H \& O'Connor DT 1998 Peptidergic activation of transcription and secretion in chromaffin cells. Cis and trans signaling determinants of pituitary adenylyl cyclase-activating polypeptide (PACAP). Journal of Clinical Investigation 101 863-876.

Thouennon E, Elkahloun AG, Guillemot J, GimenezRoqueplo AP, Bertherat J, Pierre A, Ghzili H, Grumolato L, Muresan M, Klein M et al. 2007 Identification of potential gene markers and insights into the pathophysiology of pheochromocytoma malignancy. Journal of Clinical Endocrinology and Metabolism 92 4865-4872.
Timmers H, Gimenez-Roqueplo AP, Mannelli M \& Pacak K 2009 Clinical aspects of SDHx-related pheochromocytoma and paraganglioma. Endocrine-Related Cancer 16 391-400.

Turquier V, Yon L, Grumolato L, Alexandre D, Fournier A, Vaudry H \& Anouar Y 2001 Pituitary adenylate cyclase-activating polypeptide stimulates secretoneurin release and secretogranin II gene transcription in bovine adrenochromaffin cells through multiple signaling pathways and increased binding of pre-existing activator protein-1-like transcription factors. Molecular Pharmacology 60 42-52.

Uzan B, Villemin A, Garel JM \& Cressent M 2008 Adrenomedullin is anti-apoptotic in osteoblasts through CGRP1 receptors and MEK-ERK pathway. Journal of Cellular Physiology 215 122-128.

Vandesompele J, De Preter K, Pattyn F, Poppe B, Van Roy N, De Paepe A \& Speleman F 2002 Accurate normalization of real-time quantitative RT-PCR data by geometric averaging of multiple internal control genes. Genome Biology 3 RESEARCH0034.

Vaudry D, Falluel-Morel A, Bourgault S, Basille M, Burel D, Wurtz O, Fournier A, Chow BK, Hashimoto H, Galas L et al. 2009 Pituitary adenylate cyclase-activating polypeptide and its receptors: 20 years after the discovery. Pharmacological Reviews 61 283-357.

Wang J, Shiozawa Y, Wang J, Wang Y, Jung Y, Pienta KJ, Mehra R, Loberg R \& Taichman RS 2008 The role of CXCR7/RDC1 as a chemokine receptor for CXCL12/SDF-1 in prostate cancer. Journal of Biological Chemistry 283 4283-4294.

Yon L, Guillemot J, Montero-Hadjadje M, Grumolato L, Leprince J, Lefebvre H, Contesse V, Plouin PF, Vaudry H \& Anouar Y 2003 Identification of the secretogranin II-derived peptide EM66 in pheochromocytomas as a potential marker for discriminating benign versus malignant tumors. Journal of Clinical Endocrinology and Metabolism 88 2579-2585.

Zeng ZP, Liu DM, Li HZ, Fan XR, Liu GQ, Yan WG, Tong AL \& Zheng X 2006 Expression and effect of adrenomedullin in pheochromocytoma. Annals of the New York Academy of Sciences 1073 270-276.

Ziegler CG, Brown JW, Schally AV, Erler A, Gebauer L, Treszl A, Young L, Fishman LM, Engel JB, Willenberg HS et al. 2009 Expression of neuropeptide hormone receptors in human adrenal tumors and cell lines: antiproliferative effects of peptide analogues. PNAS 106 15879-15884. 